\title{
Agronomic Performance of Corn Cultivars in Low-Altitude in the Cerrado-Amazon Ecotone
}

\author{
Weder Ferreira dos Santos ${ }^{1}$, Lara Rythelle Souza Bequiman ${ }^{2}$, \\ Lucas Carneiro Maciel ${ }^{*}$, Joênes Mucci Peluzio ${ }^{3}$, \\ Osvaldo José Ferreira Júnior ${ }^{3}$, Layanni Ferreira Sodré ${ }^{3}$, \\ Talita Pereira de Souza Ferreira ${ }^{1}$, Fernando Barnabé Cerqueira ${ }^{4}$ \\ and Lucas Alves de Faria ${ }^{3}$
}

${ }^{1}$ Department of Bioprocess Engineering and Biotechnology, Federal University of Tocantins, Gurupi, Brazil.

${ }^{2}$ Department of Agronomy, Federal University of Tocantins, Gurupi, Brazil. ${ }^{3}$ Department of Plant Production, Federal University of Tocantins, Gurupi, Tocantins, Brazil. ${ }^{4}$ Department of Agronomy, Guaraí College, Guaraí, Brazil.

Authors' contributions

This work was carried out in collaboration among all authors. Authors WFS and JMP designed the study and performed the analysis. Authors LRSB, LCM, OJFJ, LFS, TPSF and FBC managed the study and helped in the interpretation of the results. Author LAF managed the literature searches. All authors read and approved the final manuscript.

Article Information

DOI: $10.9734 / A R R B / 2020 / v 35 i 1230318$ Editor(s):

(1) Dr. Amit Kesarwani, G.B. Pant University of Agriculture \& Technology, India. (2) Dr. Paola Angelini, University of Perugia, Italy. Reviewers:

(1) Sunil Kumar Dubey, Mahalanobis National Crop Forecast Centre, India. (2) Zerihun Jida Buta, Wolkite University, Ethiopia. Complete Peer review History: http://www.sdiarticle4.com/review-history/63476

Original Research Article

Received 18 October 2020

Accepted 23 December 2020

Published 30 December 2020

\section{ABSTRACT}

Aims: The objective of this study was to evaluate the agronomic performance of corn cultivars for grain production in the south at low altitude in the Cerrado-Amazon ecotone.

Place: The research was carried out at Sítio Vitória $\left(8^{\circ} 18^{\prime} 32.0^{\prime \prime} \mathrm{S}, 50^{\circ} 36^{\prime} 58.0^{\prime \prime} \mathrm{W}, 278 \mathrm{MASL}\right)$, in the south of the state of Pará, Brazil.

Study Design: The experimental design was randomized blocks with twelve treatments and three 
replications. The treatments were eight corn hybrids: AG 1051, AG 8088, BM 3051, BR 2022, BR 205, BR 206, BRS 3046 and PR 27D28; and four open pollination populations: AL BANDEIRANTE, ANHEMBI, CATIVERDE and M 274.

Methodology: Sowed on January 28, 2019. The following characteristics were evaluated: ear height, plant height, number of grains per row, ear diameter, ear length, ear weight and grain yield.

Results: The cultivars showed a difference for all traits. The grain yield of the cultivars ranged from $4,567 \mathrm{~kg} \mathrm{ha}^{-1}$ (BR 205) to $9,450 \mathrm{~kg} \mathrm{ha}^{-1}$ (AG 1051).

Conclusion: The hybrids AG 1051 and BM 3051 were the ones that stood out the most, had the best performance in the Cerrado-Amazon ecotone.

Keywords: Grain yield; hybrids; populations of open pollination; yield components; Zea mays L.

\section{INTRODUCTION}

Corn (Zea mays L.) is among the most important crops worldwide, used in human and animal feed as an energy source, and in the production of fuel, polymers, and beverages [1]. In the world scenario of grain marketing, four countries lead the market: United States, Brazil, Argentina, and Ukraine, combined accounted for $86.2 \%$ of exports in 2017/18 [2].

In Brazil, production in 2020 was 100.6 million tons of grain, an increase of $0.5 \%$ over the previous year. And the planted area increased by $5.4 \%$ compared to the previous year, reaching 18.5 million hectares [3]. However, the mean yield grain is still low, due to the low technological level of production, little knowledge of cultivars adapted to low altitude and edaphoclimatic conditions.

The yield performance, resistance to pests, and crop stability are directly related to the cultivars on the market, each cultivar has ideal edaphoclimatic conditions of cultivation in each region [4]. To know this, cultivars must be tested in the producing regions. Agronomic performance studies of corn cultivars were conducted in several states, such as Mato Grosso do Sul [5], Tocantins [6], and Goiás [7]. However, it is still necessary to evaluate cultivars in the Cerrado-Amazon ecotone, aiming to select more adapted materials with desirable agronomic characteristics.

In agreement with the above, the present study aimed to evaluate the agronomic performance of corn cultivars for low-altitude grain production in the Cerrado-Amazon ecotone.

\section{MATERIALS AND METHODS}

The research was carried out at Sítio Vitória (8॰18'32.0"S, $50^{\circ} 36^{\prime} 58.0^{\prime \prime} \mathrm{W}, \quad 278$ MASL), municipality of Santa Maria das Barreiras, State of Pará, located in the Cerrado-Amazon ecotone (Fig. 1). The climate of the region is type Aw according to classification of Koppen, tropical with a dry season in winter [8], with maximum rainfall between October and April (Fig. 2).

The soil of the experiment presented sandy texture, with $150 \mathrm{~g} \mathrm{~kg}^{-1}$ of clay, and the following chemical attributes $(0-20 \mathrm{~cm}): 4.8 \mathrm{pH}$ $\mathrm{CaCl}_{2}, 17 \mathrm{~g} \mathrm{~kg}^{-1}$ organic matter, $4.9 \mathrm{mg} \mathrm{dm}$ phosphorus, $43 \mathrm{mg} \mathrm{dm}^{-3}$ potassium, $1.7 \mathrm{cmol}_{\mathrm{c}}$ $\mathrm{dm}^{-3}$ calcium, $0.3 \mathrm{cmol}_{\mathrm{c}} \mathrm{dm}^{-3}$ magnesium, $0.2 \mathrm{cmol}_{c} \mathrm{dm}^{-3}$ aluminum, $5.21 \mathrm{cmol}_{\mathrm{c}} \mathrm{dm}^{-3}$ cation exchange capacity, and $40 \%$ base saturation.

The experimental design was randomized blocks with twelve treatments and three replications. The treatments were corn cultivars (Table 1), of these eight corn hybrids: AG 1051, AG 8088, BM 3051, BR 2022, BR 205, BR 206, BRS 3046 and PR 27D28; and four open pollination populations: AL BANDEIRANTE, ANHEMBI, CATIVERDE and $M$ 274. The experimental units were composed of four rows of $5.0 \mathrm{~m}$, spaced $0.9 \mathrm{~m}$ between rows. The useful area was the two central rows, discarding $0.5 \mathrm{~m}$ from the ends.

The soil preparation was with a gentler grid followed by a leveling grid. The base fertilization was with $500 \mathrm{~kg} \mathrm{ha}{ }^{-1}$ of $\mathrm{N}-\mathrm{P}_{2} \mathrm{O}_{5}-\mathrm{K}_{2} \mathrm{O}$, formulation $5-25-15+0.5 \%$ Zn (Ribeiro et al. 1999). Sowing was performed on January 28, 2019, at a mean depth of $0.04 \mathrm{~m}$. After the emergency, thinning was carried out, obtaining a population of 55,555 plants ha ${ }^{-1}$.

Topdressing nitrogen fertilization was performed with $150 \mathrm{~kg} \mathrm{ha}^{-1}$ of $\mathrm{N}$, urea $(45 \%$ of $\mathrm{N})$ was divided into two applications into stages $\mathrm{V} 4$ and V8 (4 and 8 completely open leaves) [11]. The control of weed, diseases, and pests was carried 
out according to the technical recommendations of the crop [12].

The agronomic characteristics evaluated at the physiological maturation stage were: ear height and plant height with a measuring tape, considering the distance from the ground to the insertion of the first ear and last open leaf, respectively; ear diameter with the use of a caliper in the middle third of the ear; ear length with a graduated ruler; number of grains per row; ear weight; and grain yield.

Variance analysis was performed and means were compared by the Scott and Knott [13] group test, at $5 \%$ significance, using the SISVAR program [14].
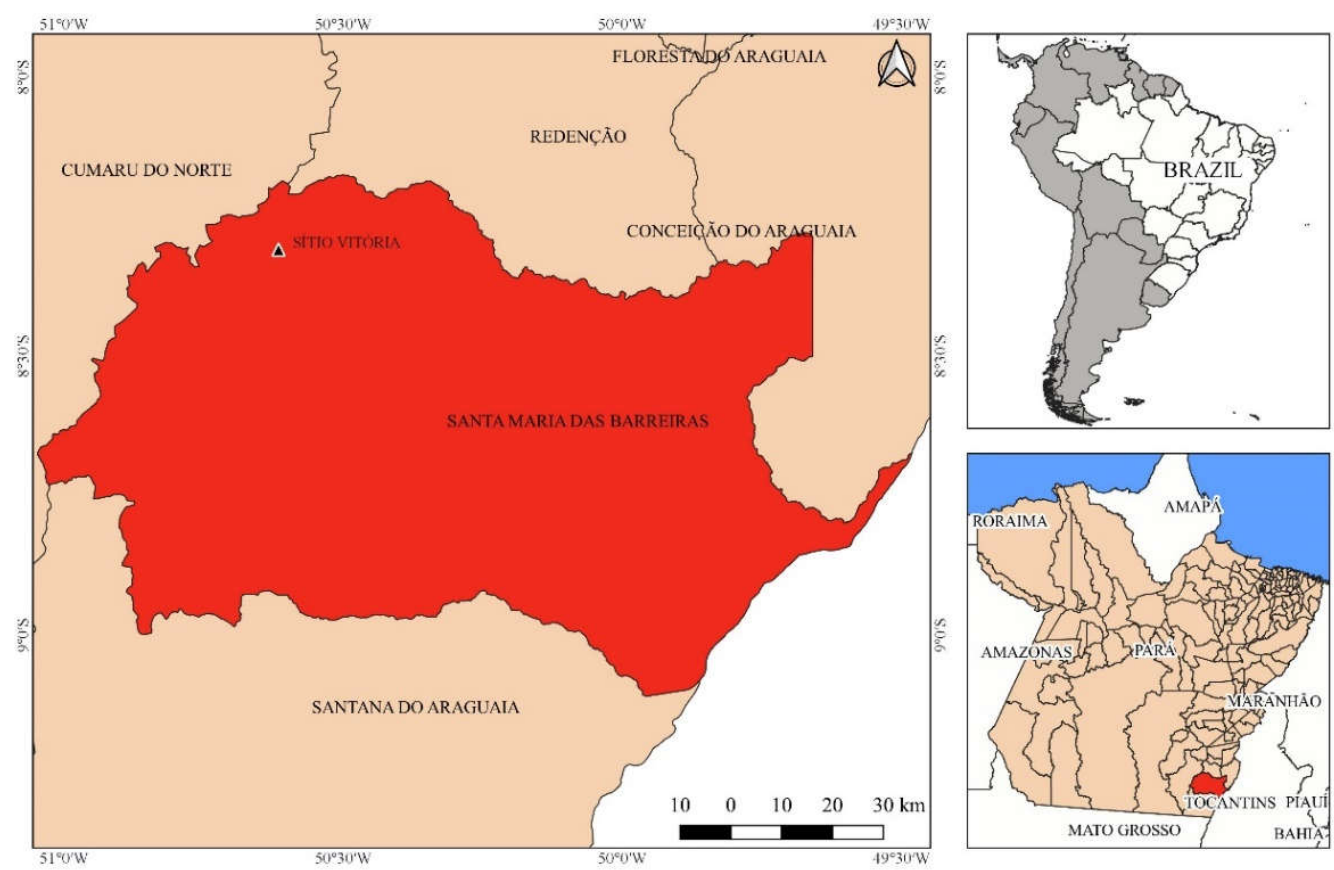

^ Sitio Vitória $\square$ Santa Maria das Barreiras $\square$ Limits of the municipalities of Pará $\square$ Limits of the states of Brazil $\square$ Limits of South America

Fig. 1. Location map of Sítio Vitória state of Pará and Brazil

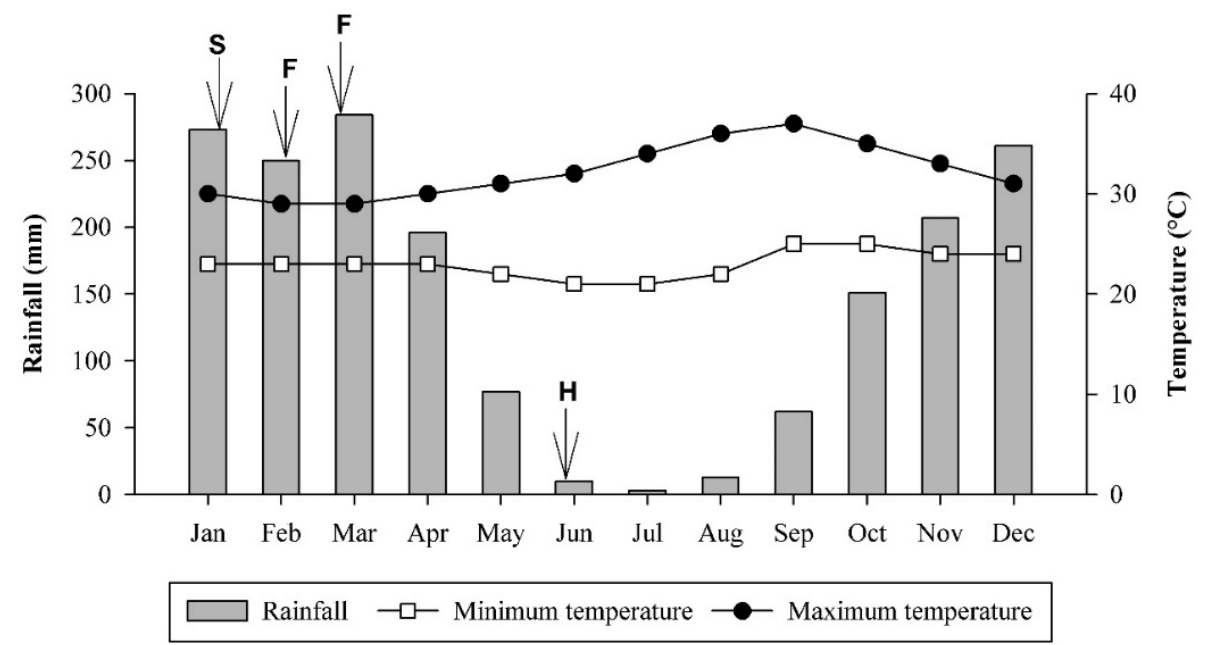

Fig. 2. Climatological means of rainfall minimum and maximum temperature of Santa Maria das Barreiras state of Pará Brazil

S: sowing, F: topdressing nitrogen fertilization, H: harvest Adapted from Climatempo [9] 
Table 1. Agronomic characteristics of corn cultivars used in the experiment

\begin{tabular}{lllll}
\hline Cultivar & Genetic Base & Cycle & Use & Technological Level \\
\hline AG 1051 & DH & SME & G/CG/WPS & M/H \\
AG 8088 & SH & E & G/WPS & H \\
AL BANDEIRANTE & OP & SME & G/WPS & L/M \\
ANHEMBI & OP & E & G/WPS & L/M \\
BM 3051 & DH & E & GC/NPS & M/H \\
BR 2022 & DH & E & G/WPS & M/H \\
BR 205 & DH & E & G/WPS & M/H \\
BR 206 & DH & E & G/WPS & M/H \\
BRS 3046 & TH & SME & GC & M/H \\
CATIVERDE & OP & SME & GC/WPS & M \\
M 274 & OP & E & G/WPS & L/M \\
PR 27D28 & DH & SE & G/WPS & L/M \\
\hline
\end{tabular}

* SH: simple hybrid; DH: double hybrid; TH: triple hybrid; OP: populations of open pollination; E: early; SME: semi-early; SE: super-early; G: grain; GC: green corn; WPS: whole plant silage; H: high; M: medium and L: low Adapted from Cruz et al. [10]

\section{RESULTS AND DISCUSSION}

The cultivars presented significant differences $(p<0.05)$ for all traits (Table 2), showing the presence of genetic variability.

Regarding plant height (Fig. 3A), two statistical groups were trained, with plant size ranging from $150 \mathrm{~cm}$ (BR 2022) to $184 \mathrm{~cm}$ (PR 27D28), and in the upper group were cultivars AG 1051, BM 3051, and PR 27D28. Silva et al. [15] analyzing 12 corn genotypes also observed a large range of plant height (142 to $175 \mathrm{~cm}$ ).

For the insertion height of the first ear (Fig. 3B), there was a variation from $62 \mathrm{~cm}$ (AG 8080 ) to $107 \mathrm{~cm}$ (AG 1051), and two groups were also formed. The cultivars belonging to the group with the highest ears were: AG 1051, PR27D28, AL BANDEIRANTES, BR 3051, and $M$ 274. The first two also presented higher plant height (Fig. 3A).

The minimum and maximum height of the insertion of the first ear recorded by Silva et al. [15], $64 \mathrm{~cm}$ and $91 \mathrm{~cm}$, we're close to those observed in the present study. However, it is emphasized that higher plant height and insertion of the first ear may favor the occurrence of layered and broken plants before harvest since taller plants tend to also increase the distance between us and reduce the diameter of the stem [16].

In the evaluation of the ear diameter (Fig. 4A) three statistical groups were formed, the group of upper cultivars was formed by AG 1051, AG 8088, BM 3051, and M 274.

The diameter of the ear is a characteristic that is directly related to the number of rows per ear, as well as grain filling [17], this characteristic together with the length of the ear, determine the productive potential of the crop [18].

The number of grains per row (Fig. 4B) was the variable that had the most cultivars in the upper group, forming only two groups. The cultivars were statistically superior: AG 1051, AG 8088, ANHEMBI, BM 3051, BR 206, M 274, and PR 27D28. In a trial of cultivars in the state of Pará, Silva et al. [19] also observed AG 1051 among the highest means. The two main factors that influence this characteristic are genetic material [20] and the efficiency of nitrogen fertilization in culture [21].

The length of the ear (Fig. 4C) ranged from 13.1 $\mathrm{cm}$ (BR 205) to $17.9 \mathrm{~cm}$ (AG 1051), and two statistical groups were formed. The cultivars AG 1051, AG 8088, BM 3051, M 274, and BR 27D28 presented longer ears. It is worth mentioning that the five cultivars that stood out in the length of the ear were also higher in the number of grains per row, which denotes the possibility of an association between these variables.

Silva et al. [19] obtained means ranging from $16.68 \mathrm{~cm}$ to $19.45 \mathrm{~cm}$, higher than that of the present experiment. The length of the ear is a characteristic related to the nutritional status of the plant, mainly the supply of $\mathrm{N}$, good water availability, and the integrity of the leaves [22]. 
For ear weight (Fig. 5A), the highest ear weight was recorded for AG $1051(218 \mathrm{~g})$ and the lowest weight for BR 205 (103 g). For this characteristic, four statistical groups were formed, the cultivars with higher weights were only AG 1051 and BM 3051.

Thus, as occurred with the ear weight, for grain yield (Fig. 5B) there was the formation of four statistical groups, where again the cultivars $A G$ 1051 and BM 3051 was higher. The minimum and maximum means were $9,450 \mathrm{~kg} \mathrm{~h}^{-1}$ (AG 1051) and 4,567 kg ha ${ }^{-1}$ (BR 205). The populations of open pollination were less productive.
Maciel et al. [23] analyzing 10 corn genotypes in Pará, we observed grain yield values between $5,446 \mathrm{~kg} \mathrm{ha}^{-1}$ to $11,486 \mathrm{~kg} \mathrm{ha}^{-1}$. Santos et al. [24] and Silva et al. [19], verified in their studies the superiority of hybrids, including AG 1051.

Therefore, based on the results of the studies, the potential for cultivation of hybrids AG 1051 and BM 3051 for grain production in the CerradoAmazon ecotone is characterized. And, the importance of evaluation programs, to ensure the correct choice of cultivars, consequently the increase of productivity and sustainability of production.

Table 2. Summary of variance analysis plant height (PH) ear height (EH) ear diameter (ED) ear length (EL) number of grains per row (NGF) ear weight (EW) and grain yield (GY) corn cultivars in low-altitude in the Cerrado-Amazon ecotone

\begin{tabular}{|c|c|c|c|c|c|c|c|c|}
\hline \multirow[t]{2}{*}{ SV } & \multirow[t]{2}{*}{ DF } & \multicolumn{7}{|c|}{ Mean Square } \\
\hline & & $\begin{array}{l}\mathrm{PH} \\
(\mathrm{cm})\end{array}$ & $\begin{array}{l}\mathrm{EH} \\
(\mathrm{cm})\end{array}$ & $\begin{array}{l}\text { ED } \\
(\mathrm{mm})\end{array}$ & $\begin{array}{l}\text { NGF } \\
\text { (No.) }\end{array}$ & $\begin{array}{l}\mathrm{EL} \\
(\mathrm{cm})\end{array}$ & $\begin{array}{l}\text { EW } \\
\text { (g) }\end{array}$ & $\begin{array}{l}\text { GY } \\
\left(\mathrm{kg} \mathrm{ha}^{-1}\right)\end{array}$ \\
\hline Cultivar & 11 & $5579^{*}$ & $5711^{*}$ & $355^{*}$ & $421^{*}$ & $101^{*}$ & $56835^{*}$ & $87618761^{*}$ \\
\hline Block & 2 & $5007^{\text {ns }}$ & $3141^{\text {ns }}$ & $40^{\mathrm{ns}}$ & $56^{\mathrm{ns}}$ & $66^{\text {ns }}$ & $12928^{\text {ns }}$ & $6713770^{\text {ns }}$ \\
\hline Error & 22 & 1326 & 1315 & 45 & 76 & 28 & 4811 & 5189290 \\
\hline Coeffici & variation (\%) & 68 & 142 & 47 & 89 & 108 & 138 & 106 \\
\hline Mean & & 16497 & 8092 & 4569 & 3100 & 1539 & 15902 & 677546 \\
\hline
\end{tabular}

* Significant and ns not significant by the F to $5 \%$ significance test SV: Source of variation; DF: Degree of freedom
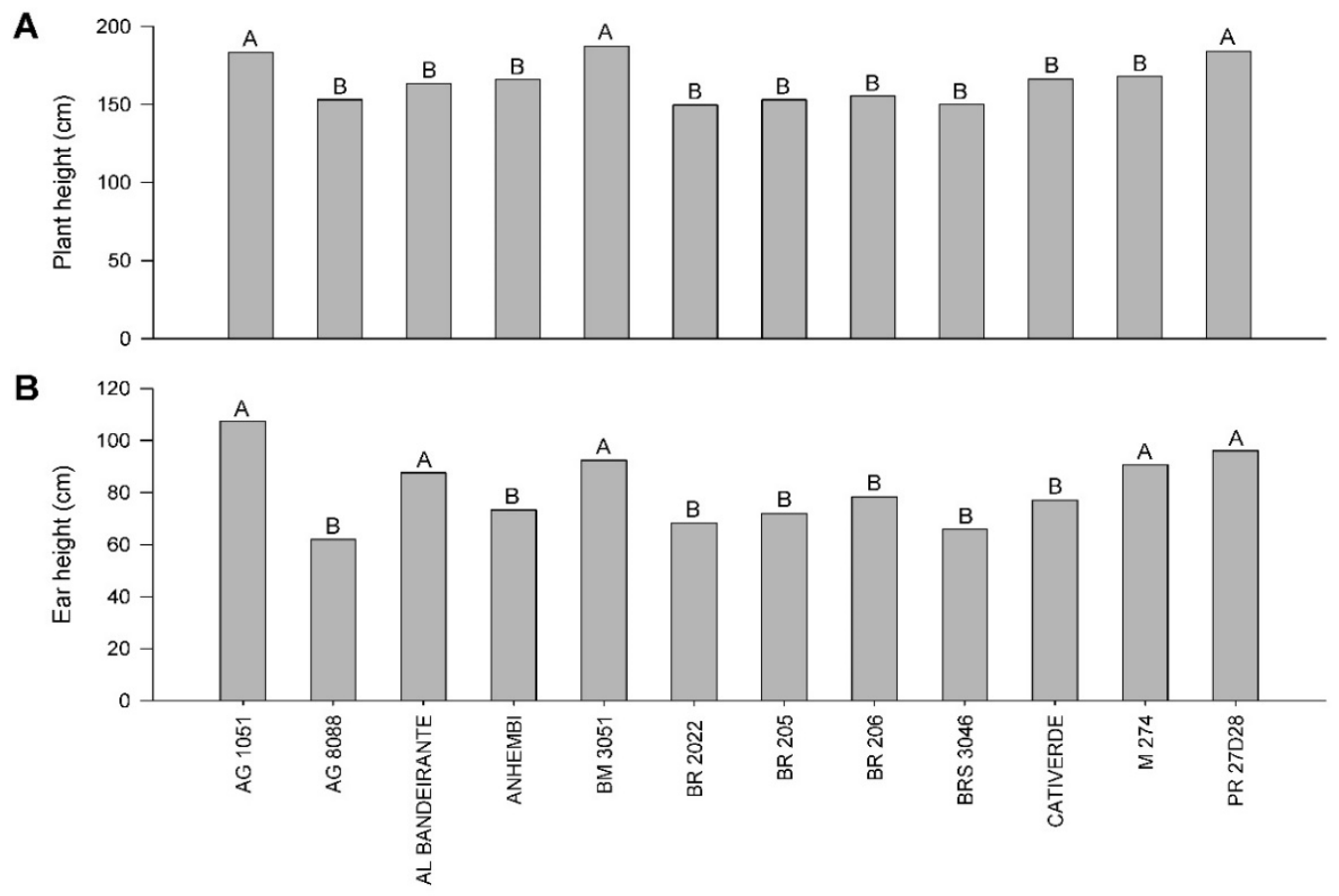

Fig. 3. Plant height (A) and ear height (B) of twelve corn cultivars in low-altitude in the CerradoAmazon ecotone 

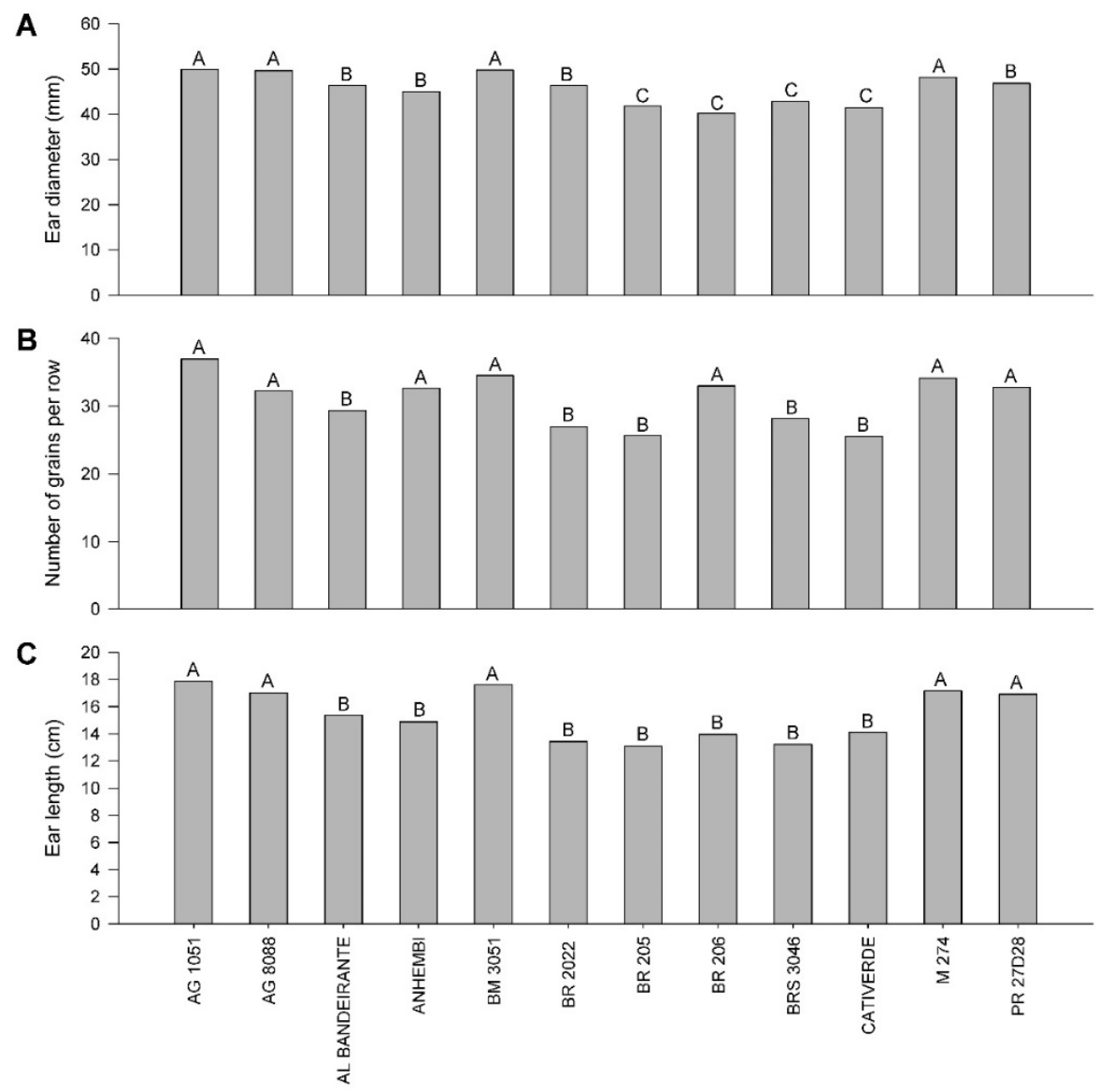

Fig. 4. Ear diameter (A) number of grains per row (B) and ear length (C) of twelve corn cultivars in low-altitude in the Cerrado-Amazon ecotone

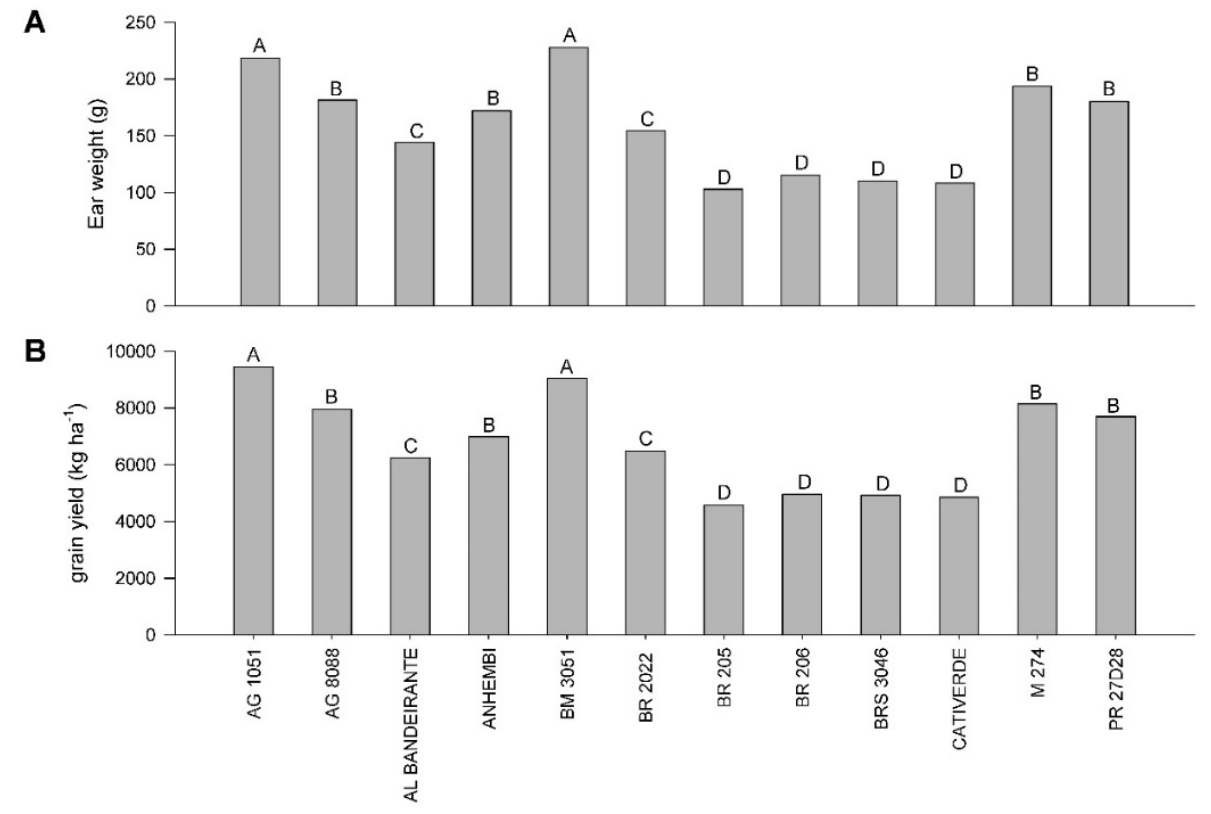

Fig. 5. Ear weight (A) and grain yield (B) of twelve corn cultivars in low-altitude in the Cerrado-Amazon ecotone 


\section{CONCLUSION}

The grain yield of the cultivars ranged from $4,567 \mathrm{~kg} \mathrm{ha}^{-1}$ and $9,450 \mathrm{~kg} \mathrm{ha}^{-1}$, of the cultivars BR 205 and AG 1051, respectively. The hybrids AG 1051 and BM 3051 presented higher means for all characteristics, had the best performance in low altitude in the CerradoAmazon ecotone.

\section{COMPETING INTERESTS}

Authors have declared that no competing interests exist.

\section{REFERENCES}

1. Miranda RA. A success story of civilization. A Granja. Portuguese. 2018;74:24-27.

2. United States department of agriculture. Grain: World markets and trade; 2020. Accessed 03 August 2020.

Available:https://www.fas.usda.gov/data/gr ain-world-markets-and-trade

3. Companhia Nacional de Abastecimento. Grain Harvest Bulletin; 2020.

Available:https://www.conab.gov.br/infoagro/safras/graos/boletim-da-safra-degraos

4. Hanashiro RK, Mingotte FLC, Fornasieri Filho D. Agronomic, morphologic and phenologic performance of maize cultivars in Jaboticabal, state of São Paulo, Brazil. Científica. 2013;41(2):226-234. Portuguese.

5. Seraguzi EF, Lima ANR, Anselmo JL, Alvarez RCF. Agronomic performance of corn hybrids in region de Chapadão do Sul, Minas Gerais state. Tecnol \& Ciên Agropec. Portuguese. 2016;10(4):12-14.

6. Santos WF, Sodre LF, Pereira JS, Pereira MS, Ferreira TPS, Cangussu ASR, Soares LB. Agronomic performance of maize genotypes. Tecnol \& Ciên Agropec. Portuguese. 2017;11(4):19-22.

7. Araújo LSI, Silva LGB, Silveira PM, Rodrigues F, Lima MLP, Cunha PCR. Agronomic performance of maize hybrids in the southeast of the State of Goias, Brazil. Portuguese. 2016;10(4):334-341. Available:Agro@mbiente on-line.

8. Dubreuil V, Pechutti Fante K, Planchon O, Neto JLS. The types of annual climates in Brazil: An application of the classification of Koppen from 1961 to 2015. EchoGéo. French. 2017;41:1-27.
9. Climatempo. Climatology: Santa Maria das Barreiras, PA; 2020. Accessed 01 September 2020.

Available:https://www.climatempo.com.br/c limatologia/6858/santamariadasbarreiraspa.

10. Cruz JC, Pereira Filho IA, Borghi E, Simão EDP. Four hundred and seventy-seven maize cultivars are available in the seed market in the 2015/16 crop. Sete Lagoas: Embrapa Milho e Sorgo; 2015.

11. Ribeiro AC, Guimarâes PTG, Alvarez VVH. Recommendations for the use of correctives and fertilizers in Minas Gerais 5th Approximation. Viçosa: Minas Gerais State Soil Fertility Commission; 1999.

12. Borém A, Galvão JCC, Pimentel MA. Corn: from planting to harvest. Viçosa: UFV; 2015.

13. Scott $A$, Knott M. Cluster analysis method for grouping means in analysis of variance. Biometrics. 1974;30:507-512.

14. Ferreira DF. Sisvar: A guide for its bootstrap procedures in multiple comparisons. Ciênc Agrotec. 2014;38(2): 109-112.

15. Silva KCL, Santos WF, Afféri FS, Peluzio JM, Sodré LF. Genetic diversity in late sowing maize genotypes under different nitrogen levels in Tocantins State, Brazil. Rev Agric Neotrop. 2019;6(3):92-100. Portuguese.

16. Sangoi L, Almeida ML, Silva PRF, Argenta G. Morpho-physiological bases for greater tolerance of modern maize hybrids to high plant densities. Bragantia. Portuguese. 2002;61(2):101-110.

17. Ohland RAA, Souza LCF, Hermani LC, Marchetti ME, Gonçalves MC. Soil cover crops and nitrogen fertilizing in corn in no tillage planting. Ciênc Agrotec. Portuguese. 2005;29(3):538-544.

18. Nakao AH, Souza MFP, Rodrigues RAF, Bem EAD, Centeno DC. Response of corn second crop in function of sources and nitrogen doses and leaf inoculation with Azospirillum brasilense. Encicl Biosf. Portuguese. 2014;10(18):2690-2701.

19. Silva RM, Santos WF, Andrade MR, Silva ZD, Santos LFS, Peluzio JM, Bequiman LRS, Luz CNM, Dias VC, Borges TASL, Martins ALL, Oliveira M. Agronomic performance and genetic divergence in corn (Zea mays) in the Cerrado-Amazon ecotone Int J Plant Soil Sci. 2019;31(1):1-7.

20. Valderrama M Buzetti S Benett CGS Filho MCMT. NPK sources and doses on 
irrigated corn under no-till system. Pesq Agropec Trop. Portuguese. 2011;41(2): 254-263.

21. Cancellier LL, Afférri FS, Carvalho EV, Dotto MA, Leão FF. Nitrogen use efficiency and phenotypic correlations of tropical maize populations in Tocantins. Rev Ciênc Agron. Portuguese. 2011;42(1): 139-148.

22. Fancelli AL, Dourado-Neto D. Corn production. Guaíba: Agropecuária; 2000.
23. Maciel LC, Santos WF, Peluzio JM, Junior OJF, Barbosa AS, Silva RM, Sodre LF, Oliveira M. Agronomic performance of corn cultivars as a function of phosphorus use. Annu Res Rev Biol. 2020;35(6):99-108.

24. Santos WF, Sodre LF, Peluzio JM, Pereira JS, Reis IM, Silva RM. Response and agronomic efficiency in maize genotypes to nitrogen fertilization in the south of Pará. Pesq Agropec Pernamb. Portuguese. 2019;24(1):1-5.

(c) 2020 Santos et al.; This is an Open Access article distributed under the terms of the Creative Commons Attribution License (http://creativecommons.org/licenses/by/4.0), which permits unrestricted use, distribution, and reproduction in any medium, provided the original work is properly cited. 